EXTENDED REPORT

\title{
Chronic non-bacterial osteomyelitis in children
}

\author{
H J Girschick, P Raab, S Surbaum, A Trusen, S Kirschner, P Schneider, T Papadopoulos, \\ H K Müller-Hermelink, P E Lipsky
}

Ann Rheum Dis 2005;64:279-285. doi: 10.1136/ard.2004.023838

See end of article for authors' affiliations .....................

Correspondence to: Dr H Girschick, Section of Paediatric Rheumatology, Children's Hospital University of Würzburg, Josef-Schneider-Str 2 97080 Würzburg,

Germany;

Hermann.Girschick@ mail.uni-wuerzburg.de

Accepted 21 April 2004

\begin{abstract}
Background: Chronic recurrent multifocal osteomyelitis (CRMO) in children is a chronic non-suppurative inflammation involving multiple sites. Some children affected by chronic non-bacterial osteomyelitis (CNO) do not have multiple lesions or a recurrent course.

Objective: To characterise the long term outcome of children with the full spectrum of CNO.

Methods: 30 children diagnosed with CNO were followed up for a mean of 5.6 years and their disease assessed using a clinical score, multiple imaging, and a diagnostic biopsy, including extensive microbial analysis.

Results: 9 patients had unifocal non-relapsing disease, 3 unifocal lesions with relapses, 9 multifocal lesions without relapses, and 9 multifocal lesions with relapses (CRMO). Granulocytes were present significantly more often in CRMO than in unifocal and non-recurrent lesions. Pustulosis was more common in multifocal cases regardless of recurrence. Mean duration of treatment in 15 children with a single occurrence was 9.2 months. Naproxen treatment was generally effective. Naproxen treatment in 12 patients with relapses lasted 25 months. However, 7 of these were not effectively treated with naproxen alone. Five were treated with oral glucocorticoids for 27 days in addition to naproxen, which induced remission in four, lasting for at least 1.5 years. Longitudinal growth of affected bones was not altered, except for the development of hyperostosis.

Conclusion: $\mathrm{CNO}$ is a spectrum of inflammatory conditions, with CRMO being the most severe. Most children with $\mathrm{CNO}$ have a favourable outcome of the disease. Oral glucocorticoids may be necessary in severe recurrent cases.
\end{abstract}

anti-inflammatory drugs (NSAIDs) has been reported to be effective. ${ }^{215} 26-31$ Occasionally, glucocorticoids, ${ }^{10}{ }^{30}$ interferon $\alpha^{32}$ interferon $\gamma$, bisphosphonates ${ }^{33}$ and very recently, tumour necrosis factor neutralising agents $\mathrm{s}^{35}$ have been used successfully in the treatment of relapsing cases. However, observations of the long term outcome of a larger cohort of affected children and evaluation of therapeutic strategies are still limited..$^{30} 36$

We prospectively followed up 30 children diagnosed with $\mathrm{CNO}$ in a community based paediatric rheumatology outpatient clinic for at least 5 years to determine whether features of this spectrum of entities were similar. The clinical course and the therapeutic impact of treatment with the NSAID, naproxen, and oral glucocorticoids in patients with frequent relapses were evaluated. Special emphasis was placed on evaluation of the disease course and a comparison of patients with unifocal and multifocal lesions, and monophasic and recurrent disease. The data suggest that $\mathrm{CNO}$ is a spectrum of disease syndromes, ranging from unifocal monophasic disease to CRMO.

\section{SUBJECTS AND METHODS \\ Patients}

Between 1991 and 2002 we diagnosed 30 children with chronic osteomyelitis including CRMO (mean age 10.3 years at onset of symptoms, range $2-17,21$ girls, 9 boys). Each patient was followed up for at least 5 years. The mean age at diagnosis was 11.0 years (range 2-21). Patients were

Abbreviations: $\mathrm{CNO}$, chronic non-bacterial osteomyelitis; CRMO, chronic recurrent multifocal osteomyelitis; CRP, C reactive protein; $C T$, computed tomography; ERA, enthesitis related arthritis; ESR, erythrocyte sedimentation rate; MRI, magnetic resonance imaging; NSAID, nonsteroidal anti-inflammatory drug; $\mathrm{PCR}$, polymerase chain reaction; $\mathrm{SAPHO}$, synovitis, acne, pustulosis, hyperostosis, osteitis/osteomyelitis 
Table 1A Clinical and laboratory features of patients with CNO

\begin{tabular}{|c|c|c|c|c|c|c|c|c|c|c|c|c|c|}
\hline CNO subset & Patient & Sex & Age & $\begin{array}{l}\text { Bone } \\
\text { lesions } \\
\text { (n) }\end{array}$ & $\begin{array}{l}\text { Joints affected by } \\
\text { arthritis }\end{array}$ & Pustulosis & HLA-B27 & ANA & $\begin{array}{l}\text { Leucocytes/I } \\
\left(\times 10^{9}\right)\end{array}$ & $\begin{array}{l}\text { ESR } \\
\text { (mm/1st h) }\end{array}$ & $\begin{array}{l}\text { CRP } \\
(\mathrm{mg} / \mathrm{l})\end{array}$ & $\begin{array}{l}\text { Ferritin } \\
(\mu \mathrm{g} / \mathrm{I})\end{array}$ & $\begin{array}{l}\text { No of } \\
\text { relapses }\end{array}$ \\
\hline \multicolumn{14}{|c|}{ Unifocal non-recurrent } \\
\hline & 6 & M & 8 y $10 \mathrm{~m}$ & 1 & Hip right & No & $\mathrm{Neg}$ & $\mathrm{Neg}$ & 5.2 & 6 & 0 & 28 & 0 \\
\hline & 11 & $\mathrm{~F}$ & 9 y $7 \mathrm{~m}$ & 1 & No & No & ND & $\mathrm{Neg}$ & 7.0 & 3 & 0 & 15 & 0 \\
\hline & 12 & M & 16 y $4 \mathrm{~m}$ & 1 & Ankle left & No & Neg & Neg & 8.5 & 17 & 13 & ND & 0 \\
\hline & 19 & $\mathrm{~F}$ & 15 y $4 \mathrm{~m}$ & 1 & Sacroiliac joint right & Yes & Neg & Neg & 4.4 & 8 & 0 & 18 & 0 \\
\hline & 21 & M & 14 y $11 \mathrm{~m}$ & 1 & Shoulder left & No & Pos & Neg & 6.7 & 8 & 0 & 14 & 0 \\
\hline & 24 & $\mathrm{~F}$ & 10 y $11 \mathrm{~m}$ & 1 & No & No & ND & ND & 12.9 & 24 & 0 & ND & 0 \\
\hline & 28 & $\mathrm{~F}$ & 1 y9 m & 1 & No & No & ND & ND & 13.5 & 22 & 0 & ND & 0 \\
\hline & 29 & $\mathrm{~F}$ & 9 y $11 \mathrm{~m}$ & 1 & Ankle left & No & $\mathrm{Neg}$ & ND & 8.7 & 10 & 0 & ND & 0 \\
\hline & 30 & $\mathrm{~F}$ & $13 y$ & 1 & Knee right & No & Neg & ND & 7.0 & 5 & 0 & 51 & 0 \\
\hline \multicolumn{14}{|c|}{ Unifocal recurrent } \\
\hline & 10 & $\mathrm{~F}$ & 3 y $10 \mathrm{~m}$ & 1 & No & No & Pos & $\mathrm{Neq}$ & 11.2 & 12 & 0 & 40 & 1 \\
\hline & 27 & $\mathrm{~F}$ & 10 y $5 \mathrm{~m}$ & 1 & No & No & $\mathrm{Neg}$ & $1: 80$ & 7.7 & 30 & 17 & ND & 2 \\
\hline & 16 & $\mathrm{~F}$ & 11 y $2 \mathrm{~m}$ & 1 & SC left & No & Neg & Neg & 5.1 & 4 & 0 & 15 & 7 \\
\hline \multicolumn{14}{|c|}{ Multifocal non-recurrent } \\
\hline & 1 & $\mathrm{~F}$ & 11 y $6 \mathrm{~m}$ & 2 & Symphysis & Yes & ND & $\mathrm{Neg}$ & 7.0 & 38 & 0 & 20 & 0 \\
\hline & 4 & $\mathrm{~F}$ & $9 y$ & 2 & SC right & No & Pos & $\mathrm{Neg}$ & 10.7 & 33 & 7 & 62 & 0 \\
\hline & 14 & $\mathrm{~F}$ & 10 y $11 \mathrm{~m}$ & 2 & Both SC & Yes & $\mathrm{Neg}$ & Neg & 5.6 & 5 & 0 & 54 & 0 \\
\hline & 20 & $\mathrm{~F}$ & 11 y $9 \mathrm{~m}$ & 2 & Hip right & No & $\mathrm{Neg}$ & Neg & 6.6 & 8 & 0 & 47 & 0 \\
\hline & 23 & M & 10 y $11 \mathrm{~m}$ & 2 & SC left & No & Pos & $\mathrm{Neg}$ & 9.0 & 24 & 0 & 48 & 0 \\
\hline & 15 & $\mathrm{~F}$ & 21 y $3 \mathrm{~m}$ & 3 & $\begin{array}{l}\text { Left metatarsal + } \\
\text { ankle }\end{array}$ & No & Pos & ND & 6.7 & 5 & 0 & 32 & 0 \\
\hline & 2 & $M$ & 7 y $8 \mathrm{~m}$ & 4 & Ankle left, SC left & Yes & ND & $\mathrm{Neg}$ & 9.1 & 10 & 0 & ND & 0 \\
\hline & 22 & $\mathrm{~F}$ & 14 y 3 m & 5 & Both SC, hip right & No & ND & Neg & 8.6 & 21 & 0 & ND & 0 \\
\hline & 26 & M & 8 y $11 \mathrm{~m}$ & 6 & No & No & $\mathrm{Neg}$ & $1: 80$ & 8.5 & 3 & 12 & 53 & 0 \\
\hline \multicolumn{14}{|c|}{ Multifocal recurrent (CRMO) } \\
\hline & 8 & $M$ & 6 y $5 \mathrm{~m}$ & 2 & Knee right & No & $\mathrm{Neg}$ & $\mathrm{Neg}$ & 7.8 & 15 & 0 & ND & 1 \\
\hline & 17 & $\mathrm{~F}$ & 9 y $8 \mathrm{~m}$ & 2 & SC left, shoulder left & No & Neg & $1: 80$ & 7.7 & 25 & 85 & 38 & 1 \\
\hline & 3 & $\mathrm{~F}$ & 13 y $1 \mathrm{~m}$ & 2 & SC left, ankle right & No & Neg & $\mathrm{Neg}$ & 13.6 & 18 & 0 & 29 & 8 \\
\hline & 5 & $\mathrm{~F}$ & 11 y $10 \mathrm{~m}$ & 3 & SC left, ankle right & Yes & Neg & ND & 12.8 & 43 & 0 & 245 & 1 \\
\hline & 9 & $\mathrm{~F}$ & 11 y 2 m & 3 & Both knees, ankle left & No & Neg & Neg & 10.8 & 20 & 29 & 16 & 2 \\
\hline & 7 & M & 6 y $10 \mathrm{~m}$ & 3 & Ankle left, SC left & No & Neg & ND & 8.2 & 7 & 0 & ND & 3 \\
\hline & 13 & $\mathrm{~F}$ & 11 y $10 \mathrm{~m}$ & 3 & Both SC & No & Neg & $\mathrm{Neg}$ & 7.9 & 15 & 0 & 37 & 4 \\
\hline & 18 & $\mathrm{~F}$ & 15 y $5 \mathrm{~m}$ & 3 & Hip left, SC left & Yes & $\mathrm{Neg}$ & Neg & 8.4 & 6 & 15 & ND & 4 \\
\hline & 25 & M & 12 y $5 \mathrm{~m}$ & 2 & $\begin{array}{l}\text { Temporomandib. } \\
\text { joint }\end{array}$ & Yes & $\mathrm{Neg}$ & Neg & 9.0 & 32 & 12 & 25 & 10 \\
\hline
\end{tabular}

SC, sternoclavicular joint; ND, not done; Neg, negative; Pos, positive; CNO, chronic non-bacterial osteomyelitis; CRMO, chronic recurrent multifocal osteomyelitis Age is given in years and months.

diagnosed with $\mathrm{CNO} / \mathrm{CRMO}$ on the basis of clinical signs of osteomyelitis (pain, local swelling, impairment of limb motion) and diagnostic procedures, including $x$ ray examination (all patients), technetium bone scan (all patients), magnetic resonance imaging (MRI; all patients), and computed tomography (CT; two patients). CT was performed when significant hyperostosis was present which was impairing function of adjacent tissues and joints (fig 2C).

In addition, diagnostic bone biopsy, including extensive microbial investigation (standard culture techniques to detect fungi, mycobacteria, aerobic and anaerobic bacteria in all samples) was done in 25 of the patients. Five patients were not biopsied because the parents refused or because a significant impairment of the affected limb or adjacent joint might have resulted from biopsy. Twelve of 25 biopsy specimens were subjected to eubacterial PCR for molecular detection of bacterial ribosomal DNA. Standard laboratory tests included blood count, erythrocyte sedimentation rate (ESR), C reactive protein (CRP), serum ferritin, serum IgG, IgM, IgA, and HLA-B27. Serology tests documenting the presence of antibodies against Borrelia burgdorferi (enzyme linked immunosorbent assay (ELISA), immunoblotting), Salmonella species, Yersinia enterocolitica, Campylobacter jejuni, and Streptococcus pyogenes were performed. Remission was defined as the absence of pain, local swelling, functional impairment of adjacent joints, in addition to a normal

Table 1B Clinical and laboratory features of patients with CNO

\begin{tabular}{|c|c|c|c|c|c|c|c|c|c|c|}
\hline CNO subset & $\begin{array}{l}\text { Delay before } \\
\text { diagnosis } \\
\text { (months) }\end{array}$ & $\begin{array}{l}\text { No of } \\
\text { relapses }\end{array}$ & $\begin{array}{l}\text { Leucocytes } \\
/ / \\
\left(\times 10^{9}\right)\end{array}$ & $\begin{array}{l}\text { ESR } \\
(\mathrm{mm} / 1 \mathrm{st} h)\end{array}$ & $\begin{array}{l}\text { CRP } \\
(\mathrm{mg} / \mathrm{l})\end{array}$ & $\begin{array}{l}\text { Ferritin } \\
(\mu \mathrm{g} / \mathrm{l})\end{array}$ & $\begin{array}{l}\lg G \\
(\mathrm{mg} / \mathrm{l})\end{array}$ & $\begin{array}{l}\lg M \\
\text { (mg/l) }\end{array}$ & $\begin{array}{l}\lg A \\
(\mathrm{mg} / \mathrm{l})\end{array}$ & $\begin{array}{l}\text { Duration of } \\
\text { naproxen } \\
\text { treatment } \\
\text { (months) }\end{array}$ \\
\hline Unifocal non-recurrent & 9.6 & NA & $8.6(3.1)$ & $11(8)$ & 1.4 & $25(15)$ & 11.75 (1.69) & $1.28(0.45)$ & $1.29(0.37)$ & $7(5.9)$ \\
\hline Unifocal recurrent & 5 & 3.3 & $8.0(3.1)$ & 15 (13) & 5.6 & 27 (18) & $10.11(1.25)$ & $1.52(0.44)$ & $1.51(0.34)$ & $24(30)$ \\
\hline Multifocal non-recurrent & +9.6 & NA & $8.0(1.6)$ & 16 (13) & 2.1 & 45 (14) & $10.80(1.64)$ & $1.18(0.44)$ & $2.04(1.14)$ & $12(14)$ \\
\hline $\begin{array}{l}\text { Multifocal recurrent } \\
\text { (CRMO) }\end{array}$ & 9.2 & 3.5 & $9.6(2.3)$ & 20 (12) & 15.6 & 65 (88) & $14.36(2.95)$ & $2.24(1.12)$ & $2.71(1.91)$ & $27.1(24.3)$ \\
\hline
\end{tabular}

Results are given as mean (SD).

Normal range of ferritin 2.3-63 $\mu \mathrm{g} / \mathrm{l}$. NA, not applicable. 
Table 2 Histological features of CNO lesions

\begin{tabular}{|c|c|c|c|c|c|c|c|c|}
\hline \multirow[b]{2}{*}{ CNO subset } & \multirow[b]{2}{*}{ Patient } & \multirow{2}{*}{$\begin{array}{l}\text { Time between } \\
\text { first symptom } \\
\text { and diagnosis } \\
\text { (months) }\end{array}$} & \multirow{2}{*}{$\begin{array}{l}\text { Bone lesions } \\
\text { (n) }\end{array}$} & \multirow{2}{*}{$\begin{array}{l}\text { Bones affected } \\
\text { (n) }\end{array}$} & \multicolumn{2}{|c|}{ Cellular predominance in bone lesions } & \multirow[b]{2}{*}{ Hyperostosis } & \multirow[b]{2}{*}{$\begin{array}{l}\text { Fibrosis of the } \\
\text { marrow space }\end{array}$} \\
\hline & & & & & $\begin{array}{l}\text { Monocytes/ } \\
\text { lymphocytes }\end{array}$ & Granulocytes & & \\
\hline \multicolumn{9}{|c|}{ Unifocal non-recurrent } \\
\hline & 6 & 26 & 1 & 1 & ++ & - & + & + \\
\hline & 11 & 4 & 1 & 1 & ND & ND & ND & ND \\
\hline & 12 & 18 & 1 & 1 & ND & ND & ND & ND \\
\hline & 19 & 4 & 1 & 1 & + & - & $(+)$ & + \\
\hline & 21 & 12 & 1 & 1 & + & - & + & + \\
\hline & 24 & 1 & 1 & 1 & + & - & - & - \\
\hline & 28 & 1 & 1 & 1 & + & - & - & $(+)$ \\
\hline & 29 & 9 & 1 & 1 & ND & ND & ND & ND \\
\hline & 30 & 12 & 1 & 1 & + & - & - & - \\
\hline \multicolumn{9}{|c|}{ Unifocal recurrent } \\
\hline & 10 & 3 & 1 & 1 & + & - & - & + \\
\hline & 27 & 1 & 1 & 1 & + & - & + & - \\
\hline & 16 & 11 & 1 & 1 & + & - & + & + \\
\hline \multicolumn{9}{|c|}{ Multifocal non-recurrent } \\
\hline & 1 & 1 & 2 & 2 & + & $(+)$ & $(+)$ & + \\
\hline & 4 & 2 & 2 & 2 & + & - & - & + \\
\hline & 14 & 18 & 2 & 2 & ND & ND & ND & ND \\
\hline & 20 & 9 & 2 & 2 & + & - & ++ & + \\
\hline & 23 & 7 & 2 & 2 & + & + & + & + \\
\hline & 15 & 36 & 3 & 3 & + & - & + & - \\
\hline & 2 & 1 & 4 & 4 & + & - & + & + \\
\hline & 22 & 12 & 5 & 5 & + & $(+)$ & - & + \\
\hline & 26 & 1 & 6 & 2 & ND & ND & ND & ND \\
\hline \multicolumn{9}{|c|}{ Multifocal recurrent (CRMO) } \\
\hline & 8 & 12 & 2 & 2 & + & - & + & - \\
\hline & 17 & 2 & 2 & 2 & + & $(+)$ & + & + \\
\hline & 3 & 13 & 2 & 2 & + & + & + & + \\
\hline & 5 & 4 & 3 & 3 & $(+)$ & + & + & + \\
\hline & 9 & 20 & 3 & 3 & $(+)$ & $(+)$ & + & + \\
\hline & 7 & 26 & 3 & 3 & $(+)$ & + & + & + \\
\hline & 13 & 3 & 3 & 3 & + & ++ & + & - \\
\hline & 18 & 2 & 3 & 3 & + & + & + & + \\
\hline & 25 & 1 & 2 & 2 & + & + & + & + \\
\hline
\end{tabular}

number of leucocytes in the peripheral blood and normalisation of the ESR and CRP. In addition, signs of inflammation must not be present by MRI.

To assess the inflammatory activity of the bone lesions during follow up, the outcome measures included an indepth physical examination in addition to MRI and standard $x$ ray examination. Bone scans were not routinely performed. Only when a relapse was diagnosed, was an additional bone scan performed to assess a unifocal or multifocal course. Clinical findings, the diagnostic value of histopathology, microbiology, and imaging techniques of 14 of the patients have been reported in part previously. ${ }^{27}{ }^{38}$ In this study the long term outcome of a larger cohort of 30 patients, as well as the therapeutic impact of treatment with the NSAID, naproxen $(15 \mathrm{mg} / \mathrm{kg} /$ day), and oral glucocorticoids were evaluated. The study was performed according to the principles of the Declaration of Helsinki. Relapse was defined as re-emerging pain, local swelling, and the presence of inflammation shown by MRI.

\section{Preparation and amplification of bacterial ribosomal DNA from biopsy specimens}

Bacterial ribosomal DNA analysis by PCR was done in 12 biopsy specimens of 12 different patients using procedures described previously. ${ }^{23}$ For detection of eubacteria by universal 16S rDNA amplification, DNA was extracted from biopsy tissue using a QiaAmp DNA mini kit (Qiagen). Universal 16S rDNA amplification was done with primers

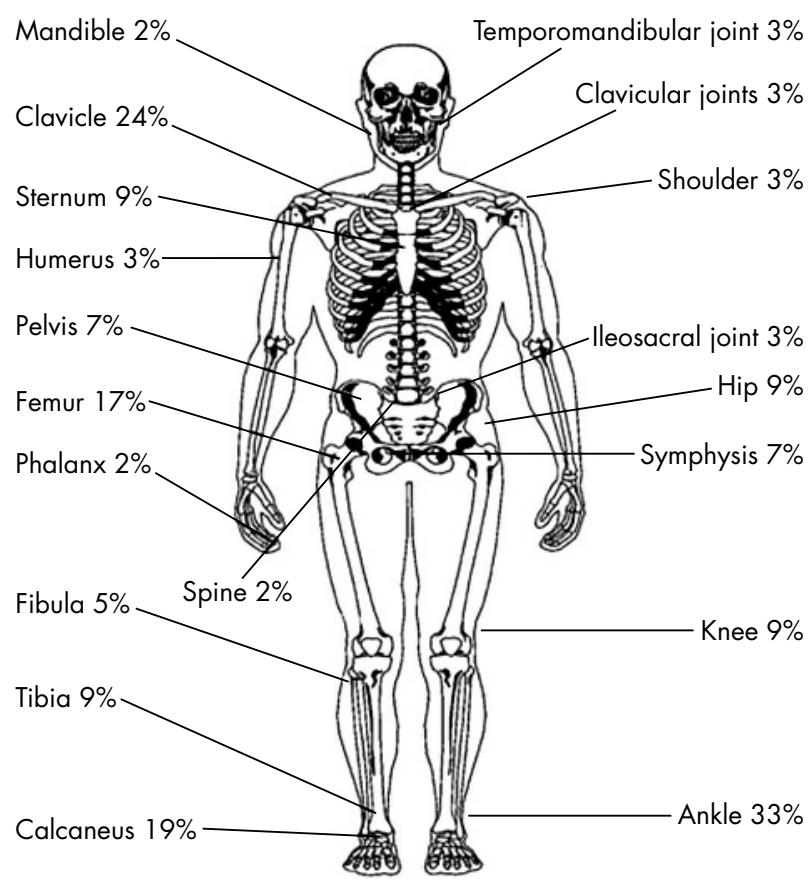

Figure 1 Bone (left) and joint (right) involvement in 30 paediatric patients with $\mathrm{CNO}$. 
BAKllw (5'-AGTTTGATCHTGGCTCAG-3') and PC3mod

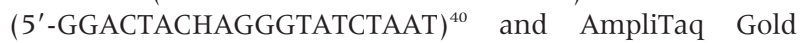
Polymerase (Applied Biosystems). Positive and negative controls were included in all assays, as well as controls in which the samples were spiked with positive control DNA to detect the presence of PCR reaction inhibitors. The detection limit ranges from 20 to 1000 bacteria for most eubacteria.

\section{Statistical analysis}

The Mann-Whitney rank sum test and the $\chi^{2}$ test were used to analyse differences between the four clinical groups of patients with CNO.

\section{RESULTS \\ Clinical features \\ Osteomyelitis}

There was a mean delay of 8 months in making the diagnosis after the first symptoms had appeared (mean age 10.3 years at onset). Of 30 patients with CNO, nine had a unifocal lesion with no relapse, three a unifocal lesion with relapses, nine multifocal lesions without relapses, and nine multifocal lesions with relapses (consistent with the diagnosis CRMO). In 30 patients, a total of 59 individual bones were affected by the inflammatory process (tables 1A, B and 2). A mean of two bones were affected in each patient (range 1-6; table 2). The clavicle was involved 14 times in 59 affected bones $(24 \%)$, whereas $11 / 30(37 \%)$ patients had a clavicular lesion. The anterior chest wall, including the sternum, accounted for $6 / 59$ (10\%) bone lesions, whereas 5/30 (16\%) patients had an anterior chest wall lesion. Figure 1 shows the prevalence of affected bones. The total number of bone lesions was 63 and, therefore, multiple lesions of one particular bone were not seen except in one patient (table 2). There were no significant differences in the pattern of affected individual bones comparing the four $\mathrm{CNO}$ subsets ( $\chi^{2}$ test) (table 3$)$.

The difference in recurrence of unifocal compared with multifocal courses was not significant $(p=0.914$, MannWhitney rank sum test, table 1 ). The patient's history showed evidence suggestive of bronchial infections as a possible trigger for a relapse in only $4 / 12$ patients.

\section{Arthritis}

It has been suggested that CRMO belongs to the spectrum of spondyloarthropathies affecting not only the joints but also, primarily, the bone. ${ }^{73}$ Initially, and during the course of disease, $24 / 30(80 \%)$ patients were diagnosed with arthritis of the joints adjacent to the lesion by physical examination and MRI (table 1). Synovial biopsies of five patients showed synovitis. In 24 patients with $\mathrm{CNO}$ and arthritis, a total of 33 joints were affected (fig 1). Three of the patients also fulfilled the International League Against Rheumatism criteria for "enthesitis related arthritis" ${ }^{41}$ at the time of presentation and two of the three still had active joint disease at the last follow up. Another two patients were diagnosed with "enthesitis related arthritis" after 5 and 8 years of follow up. ${ }^{41}$ In addition, all five patients ( $17 \%$ of the patients) also satisfied the European Spondylarthropathy Study group criteria for spondyloarthropathy. ${ }^{42} 43$ One of five was HLA-B27 positive.
No sacroiliitis evolved during follow up, whereas one patient was noted to have unilateral sacroiliitis at the time of diagnosis.

\section{Skin lesions}

Pustulosis of the skin was present in $23 \%$ of patients (fig 2). In general, skin lesions tended to improve during the first year using emollients. Four of the five patients with palmoplantar involvement had complete remission of their skin lesions at the last follow up.

\section{Laboratory tests}

Initial laboratory data (tables $1 \mathrm{~A}$ and $\mathrm{B}$ ) showed a mean of $8.6 \times 10^{9}$ leucocytes/l (range $4.4-13.6 \times 10^{9} / 1$ ), a mean haemoglobin level of $132 \mathrm{~g} / \mathrm{l}$ (range 114-144 g/l), a mean ESR of $15 \mathrm{~mm} / \mathrm{lst} \mathrm{h}$ (range $3-43 \mathrm{~mm} / \mathrm{lst} \mathrm{h}$ ), and a mean ferritin level of $40.9 \mu \mathrm{g} / \mathrm{l}$ (range 12-245 $\mu \mathrm{g} / \mathrm{l}$, all normal except one multifocal recurrent patient). ESR, peripheral blood leucocytes, and ferritin did not differ between the different CNO groups (table 1, Mann-Whitney rank sum test).

All patients had normal serum IgG levels (mean $12.03 \mathrm{~g} / \mathrm{l}$ ), except three patients with CRMO (Nos 3, 5, 17) who had slightly raised levels. There was a significant difference in the IgG levels between multifocal non-recurrent and CRMO cases $(\mathrm{p}=0.019$, Mann-Whitney rank sum test), but not between the other groups and not between unifocal and multifocal cases regardless of the recurrent nature.

Serum IgM levels were moderately raised in four multifocal cases (Nos 3, 4, 5, 17) (mean $1.43 \mathrm{~g} / \mathrm{l}($ all)). There was a significant difference in the IgM levels between multifocal non-recurrent and CRMO cases $(p=0.04$, Mann-Whitney rank sum test), but not between the other groups and not between unifocal and multifocal courses regardless of the recurrent nature.

Serum IgA levels were raised in three multifocal patients (Nos 3, 5, 23) (mean $2.34 \mathrm{~g} / \mathrm{l}$ (all), range 0.71-6.54). There was a significant difference between the IgA levels of the unifocal and multifocal cases regardless of the recurrent nature $(p=0.045$, Mann-Whitney rank sum test), but not between the individual groups.

None of the patients clinically or serologically showed signs of acute or chronic infection with Borrelia burgdorferi, Salmonella enteritidis, Yersinia enterocolitica, and Campylobacter jejuni. Four patients had raised anti-streptolysin-O and antistreptococcal DNA titres.

Antinuclear antibody levels were negative. The prevalence of HLA-B27 was $21 \%$. This differs from the prevalence of HLA-B27 $(9 \%)$ in the local population $\left(p=0.043, \chi^{2}\right.$ goodness of fit test). Antinuclear antibody levels and the prevalence of HLA-B27 did not differ between the CNO groups (table $1, \chi^{2}$ test).

\section{Course of disease \\ Histology}

All 25 biopsies were consistent with the diagnosis of chronic osteomyelitis $^{2}$ (table 2). There was a predominance of $\mathrm{CD} 3(+), \mathrm{CD} 45 \mathrm{RO}(+) \mathrm{T}$ cells, which were mainly $\mathrm{CD} 4(-)$ and CD8(+). CD20(+) B cell infiltrates were uncommon. CD68(+) monocytes or macrophages were abundant. Reparative

Table 3 Distribution of bone lesions in CNO

\begin{tabular}{|c|c|c|c|c|c|c|c|c|c|c|c|}
\hline CNO pattern/bone lesion & Clavicle & Chest & Humerus & Phalanx & Spine & Pelvis & Femur & Tibia & Fibula & Calcaneus & Skull \\
\hline Unifocal non-recurrent (n) & 1 & & 1 & & 1 & & 3 & 1 & & 1 & 1 \\
\hline Unifocal recurrent $(n)$ & 1 & & 1 & & & & & & 1 & & \\
\hline Multifocal non-recurrent (n) & 7 & 3 & & & & 4 & 3 & & 2 & 9 & \\
\hline Multifocal recurrent (CRMO) (n) & 6 & 3 & & 1 & & & 4 & 3 & 1 & 4 & 1 \\
\hline
\end{tabular}




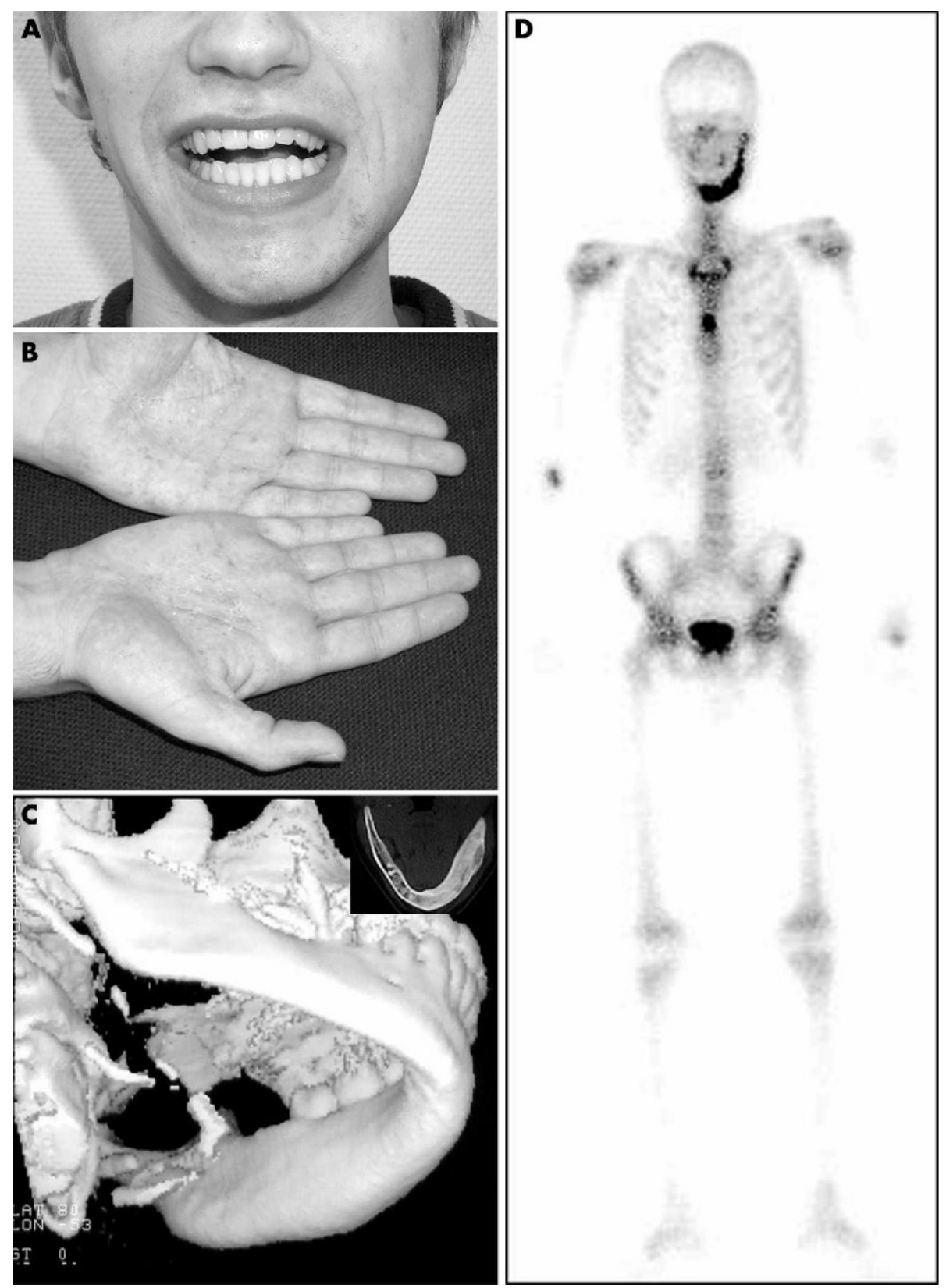

Figure 2 Clinical synopsis of a 20 year old male patient with a history of 7.5 years of CNO.

changes of the osseous tissue (marrow fibrosis, trabecular osteoid apposition, periosteal hyperostosis) were prominent in 19/25 biopsies. Granulocytes were present more often in CRMO than in unifocal non-recurrent $(\mathrm{p}<0.001)$ or in multifocal non-relapsing lesions $\left(p<0.05, \chi^{2}\right.$ test; table 2$)$. Hyperostosis was present more often in CRMO than in unifocal non-recurrent lesions $\left(\mathrm{p}<0.05, \chi^{2}\right.$ test; table 2$)$. There were no significant differences in hyperostosis between the other groups. Histological differences could not be attributed to a delay in diagnosis.

\section{Treatment}

A total of 27 patients were treated with naproxen $(15 \mathrm{mg} / \mathrm{kg} /$ day) for an overall mean duration of 13.4 months. The mean duration of symptoms in the group of 18 patients with one single occurrence (unifocal and multifocal) was 6 months. Fifteen of these 18 patients were treated with naproxen, with a mean duration of treatment of 9 months. In general, remission was achieved with naproxen in this group. Despite hyperostosis, patients were considered to be in remission if signs of acute inflammation were absent. There was no significant difference in the duration of naproxen treatment between the unifocal and multifocal non-recurrent subset $(\mathrm{p}=0.27$, Mann-Whitney rank sum test).

Mean duration of naproxen treatment in cases with relapses was 25 months. The mean length of a relapse was 3 months. Naproxen alone was only sufficient to achieve long term remission in 5/12 patients with relapses. In one patient with relapses, naproxen treatment was successfully switched to meloxicam, another patient was treated successfully by adding sulfasalazine. There was no significant difference in the duration of naproxen treatment between the unifocal and multifocal recurrent subset $(p=0.52$, Mann-Whitney rank sum test). The difference in the mean duration of naproxen 
treatment in unifocal non-relapsing cases and the CRMO subset was significant $(\mathrm{p}=0.028$, Mann-Whitney rank sum test).

One of nine patients with multifocal non-relapsing disease did not achieve remission with naproxen alone. Treatment with oral glucocorticoids for 27 days (prednisone $2 \mathrm{mg} / \mathrm{kg} /$ day over 7 days, followed by $1.5 \mathrm{mg} / \mathrm{kg} /$ day for 4 days, $1 \mathrm{mg} /$ $\mathrm{kg} /$ day for 4 days, $0.5 \mathrm{mg} / \mathrm{kg} /$ day for 4 days, $0.25 \mathrm{mg} / \mathrm{kg} /$ day for 4 days, $0.25 \mathrm{mg} / \mathrm{kg} /$ day alternating over 4 days) in addition to naproxen achieved long term remission for currently 3 years. Four of nine patients with CRMO with four or more relapses were treated with the same glucocorticoid regimen in addition to naproxen. This induced remission in 3/4 patients, which so far has lasted for at least 2.5 years. The fifth patient (fig 2) also achieved remission. However, the patient's disease flared 6 months later while still being treated with naproxen. Additional treatment strategies (sulfasalazine, bisphosphonate, ${ }^{34}$ hyperbaric oxygen treatment, surgical decortication) did not induce remission. Steroid treatment was well tolerated. Notably, in $6 / 25$ (24\%) patients the biopsied bone relapsed, whereas $8 / 30$ patients had relapses in bones without previous biopsy $(27 \%)$.

\section{Long term outcome}

Biopsied as well as non-biopsied lesions were in remission exhibiting sclerosis in all and hyperostosis in 17/59 affected bones after 5 years. No longitudinal growth disturbances were noted in the affected bones. However, one patient (fig 2) had functional impairment of the masticatory system. ${ }^{44}$ None of the patients developed malignant diseases.

In 30 patients a total of 59 different bones were affected by osteitis. Twenty four of 30 patients were affected by arthritis and osteitis. The total number of affected joints in these 24 patients was 30 . The percentages of affected bones (left side of fig 1) or joints (right side of fig 1) are shown.

Figure 2A shows the maximal mouth opening and left sided mandibular hypertrophy of the patient (No 25 in table 1) during relapse. The adolescent man was affected by mild palmar pustulosis (fig 2B). Mandibular hypertrophy is documented in a three dimensional CT scan in addition to osteolysis of the cortical bone (fig 2C). Technetium-99m MDP bone scan shows the involvement of almost two thirds of the mandible and a clinically silent sternal lesion (fig 2D).

\section{DISCUSSION}

\section{Unifocal and multifocal course of disease}

CRMO in children has been recognised as a clinical entity for almost three decades. ${ }^{111} 161838$ 45-51 Recurrence and multiplicity of lesions may not be present in every patient initially or during the course of disease. In our cohort, patients with unifocal lesions could have a non-relapsing course or undergo relapses. Even though unifocal cases seemed to show less signs of inflammation as indicated by histology and laboratory data, patients with unifocal lesions, in principle, had comparable clinical and histological characteristics to those of patients with multiple lesions. Indeed, on occasion, single lesions were refractory to treatment. Pustulosis of the skin was present more often, but not significantly, in multifocal cases. One reason for the absence of multiple lesions and a lack of relapses might be early treatment with an NSAID in this cohort of patients. The likelihood that CNO is a spectrum of conditions ranging from an unifocal nonrecurrent course of disease to CRMO is illustrated by patient No 25 (fig 2), who in the first 5 years of disease exhibited one chronic recurrent lesion in the mandible. After 5 years the patient met the criteria for CRMO, with a second lesion in the sternum and palmar pustulosis.

\section{Is arthritis a feature of CNO?}

Recently, evolution of CRMO into enthesitis related arthritis (ERA) or spondyloarthropathy has been documented in two cohorts of children and young adults. ${ }^{70}$ However, joint involvement at the time of diagnosis might have been underestimated. In our cohort, joints were often affected and the degree of involvement did not differ between the different CNO subsets. In our clinic we have 79 patients affected by ERA; five $(6 \%)$ of those were also diagnosed with CNO. During follow up, two patients had CNO which evolved after 5 and 8 years into ERA. Even though evolution of CNO into ERA is uncommon, the overlap of clinical features documents the need for long term follow up. ${ }^{52}$

\section{Treatment}

In our experience NSAIDs are the first choice for the initial treatment and for the treatment of relapses. This is consistent with published experience in other cohorts. ${ }^{7} 142830$ 53-55 However, multifocality or frequent relapses might require more intensive anti-inflammatory treatment, including steroids. ${ }^{55}$ It is important to note that this was not a placebo controlled study, so the efficacy of treatment can only be estimated. However, when our cohort is compared with reported historical controls and subjects in our clinic, in whom the natural course of disease has been followed up over a prolonged time period, it seems evident that NSAID treatment is effective. Thus, the prevalence of disability at the last follow up in our NSAID and glucocorticoid treated cohort is much less than in non-treated controls ( $1 / 30$ patients compared with $4 / 7$ historic control patients ${ }^{17}$ and $3 / 3$ of our own CRMO cases). In one of the earliest CRMO cohorts reported by Bjorksten et al the mean duration of symptoms was 6.3 years, ${ }^{53}$ compared with 19 months in our cohort.

\section{CONCLUSION}

We consider that unifocal osteomyelitis lesions which prove to be sterile and which fulfil the histological criteria of $\mathrm{CNO} /$ CRMO, ${ }^{214}$ belong to the same clinical spectrum as CRMO. $\mathrm{CNO}$ in our experience manifests as a spectrum of nonbacterial osteomyelitis in children, which in some patients may evolve into spondyloarthropathy. As long as molecular or genetic diagnostic criteria are not available, we propose that the descriptive name chronic non-bacterial osteomyelitis (CNO) might be more appropriate than CRMO. CRMO should be used only if a multifocal and recurrent course of disease is present.

\section{Authors' affiliations \\ H J Girschick, Department of Paediatrics, University of Würzburg, Germany}

P Raab, S Kirschner, Section of Paediatric Orthopaedics, University of Würzburg, Germany

S Surbaum, Department of Microbiology, University of Würzburg, Germany

A Trusen, Department of Radiology, Section of Paediatric Radiology, University of Würzburg, Germany

P Schneider, Clinic for Nuclear Medicine, University of Würzburg,

Germany

T Papadopoulos, Department of Pathology, University of Erlangen, Germany

H K Müller-Hermelink, Department of Pathology, University of Würzburg, Germany

P E Lipsky, NIAMS, NIH, Bethesda, MD, USA

None of the authors have a conflict of interest with respect to the drugs mentioned in this paper.

\section{REFERENCES}

1 Reith JD, Baver TW, Schils JP. Osseous manifestations of SAPHO (synovitis, acne, pustulosis, hyperostosis, osteitis) syndrome. Am J Surg Pathol 1996;20:1368-77. 
2 Girschick HJ, Huppertz HI, Harmsen D, Krauspe R, Muller-Hermelink HK Papadopoulos T. Chronic recurrent multifocal osteomyelitis in children: diagnostic value of histopathology and microbial testing. Hum Pathol 1999:30:59-65.

3 Weihe S, Eufinger H, Terhaar O, Konig M, Machtens E. Mandibular involvement in chronic recurrent multifocal osteomyelitis (CRMO) in adulthood. Mund Kiefer Gesichtschir 2000;4:187-92.

4 Schilling $F$, Eckardt A, Kessler S. Chronic recurrent multifocal osteomyelitis. Z Orthop Ihre Grenzgeb 2000;138:530-9.

5 Schilling F, Kessler S. Chronic recurrent multifocal osteomyelitis-I. Review. Klin Padiatr 2001;213:271-6.

6 Jurriaans E, Singh NP, Finlay K, Friedman L. Imaging of chronic recurrent multifocal osteomyelitis. Radiol Clin North Am 2001;39:305-27.

7 Vittecoq O, Said LA, Michot C, Mejiad O, Thomine JM, Mitrofanoff P, et al. Evolution of chronic recurrent multifocal osteitis toward spondylarthropathy over the long term. Arthritis Rheum 2000;43:109-19.

8 Schultz C, Holterhus PM, Seidel A, Jonas S, Barthel M, Kruse K, et al. Chronic recurrent multifocal osteomyelitis in children. Pediatr Infect Dis J 1999; 18:1008-13.

9 Jurik AG, Moller BN. Chronic sclerosing osteomyelitis of the clavicle. A manifestation of chronic recurrent multifocal osteomyelitis. Arch Orthop Trauma Surg 1987; 106:144-51.

10 Pelkonen P, Ryoppy S, Jaaskelainen J, Rapola J, Repo H, Kaitila I. Chronic osteomyelitis-like disease with negative bacterial cultures. Am J Dis Child 1988;142:1167-73

11 Jurik AG, Moller BN, Jensen MK, Jensen JT, Graudal H. Sclerosis and hyperostosis of the manubrium sterni. Rheumatol Int 1986:6:171-8.

12 Kahn MF, Bouvier M, Palazzo E, Tebib JG, Colson F. Sternoclavicular pustulotic osteitis (SAPHO). 20-year interval between skin and bone lesions. $J$ Rheumatol 1991;18:1104-8.

13 Kahn MF, Chamot AM. SAPHO syndrome. Rheum Dis Clin North Am 1992; 18:225-46.

14 Carr AJ, Cole WG, Roberton DM, Chow CW. Chronic multifocal osteomyelitis. J Bone Joint Surg Br 1993;75:582-91.

15 BjOrksten B, Boquist L. Histopathological aspects of chronic recurrent multifocal osteomyelitis. J Bone Joint Surg Br 1980;62:376-80.

16 Jurik AG, Moller BN. Inflammatory hyperostosis and sclerosis of the clavicle. Skeletal Radiol 1986;15:284-90.

17 Yu L, Kasser JR, O'Rourke E, Kozakewich H. Chronic recurrent multifocal osteomyelitis. Association with vertebra plana. J Bone Joint Surg Am 1989;71:105-12.

18 Mollan RA, Craig BF, Biggart JD. Chronic sclerosing osteomyelitis. An unusual case. J Bone Joint Surg Br 1984;66:583-5.

19 Hummell DS, Anderson SJ, Wright PF, Cassell GH, Waites KB. Chronic recurrent multifocal osteomyelitis: are mycoplasmas involved? N Engl J Med 1987;317:510-1

20 Le Goff P, Brousse A, Fauquert P, Guillet G, Leroy JP. Anterior thoracic and intervertebral erosive joint diseases associated with palmoplantar pustulosis. Rev Rhum Mal Osteoartic 1985;52:391-6.

21 Schilling F, Wagner AD. Azithromycin: an anti-inflammatory effect in chronic recurrent multifocal osteomyelitis? A preliminary report. Z Rheumatol 2000;59:352-3.

22 Waldvogel K, Regnery RL, Anderson BE, Caduff R, Caduff J, Nadal D. Disseminated cat-scratch disease: detection of Rochalimaea henselae in affected tissue. Eur J Pediatr 1994;153:23-7.

23 Poujol A, Toesca S, Di Marco JN, Rimet Y, Tissot Dupont H, Mace L, et al. Recurrent osteitis and Coxiella burnetii: the relation to chronic recurrent multifocal osteomyelitis. Arch Pediatr 1998;5:291-4

24 Uhl M, Leichsenring $M$, Krempien $B$. Chronically recurring multifocal osteomyelitis. Rofo Fortschr Geb Rontgenstr Neuen Bildgeb Verfahr 1995; 162:527-30.

25 Reinehr T, Burk G, Michel E, Andler W. Chronic osteomyelitis in childhood: is surgery always indicated? Infection 2000;28:282-6.

26 Tan BS, Nayanar V, Mansberg R, Murray IP, Rossleigh MA. Two cases of chronic recurrent multifocal osteomyelitis: radiological and scintigraphic findings. Australas Radiol 1996;40:437-41.

27 Sundaram M, McDonald D, Engel E, Rotman M, Siegfried EC. Chronic recurrent multifocal osteomyelitis: an evolving clinical and radiological spectrum. Skeletal Radiol 1996;25:333-6.

28 Van Howe RS, Starshak RJ, Chusid MJ. Chronic, recurrent multifocal osteomyelitis. Case report and review of the literature. Clin Pediatr (Phila) 1989;28:54-9.

29 Handrick W, Hormann D, Voppmann A, Schille R, Reichardt P, Trobs RB, et al. Chronic recurrent multifocal osteomyelitis - report of eight patients. Pediatr Surg Int 1998;14:195-8.
30 Job-Deslandre C, Krebs S, Kahan A. Chronic recurrent multifocal osteomyelitis: five-year outcomes in 14 pediatric cases. Joint Bone Spine $2001 ; 68: 245-51$.

31 Schuster T, Bielek J, Dietz HG, Belohradsky BH. Chronic recurrent multifocal osteomyelitis (CRMO). Eur J Pediatr Surg 1996;6:45-51.

32 Andersson R. Effective treatment with interferon-alpha in chronic recurrent multifocal osteomyelitis. J Interferon Cytokine Res 1995;15:837-8.

33 Schilling F, Coerdt W, Eckardt A, Full H, Hospach T, Kessler S, et al. Pelvic type of chronic recurrent multifocal osteomyelitis. Klin Padiatr $2001 ; 213: 277-84$

34 Akikusa JD, Zacharin M, Shugg AW, Allen RC. Bisphosphonates in the treatment of chronic recurrent multifocal osteomyelitis. Arthritis Rheum $2001 ; 44: 171$.

35 Wagner AD, Andresen J, Jendro MC, Hulsemann JL, Zeidler H. Sustained response to tumor necrosis factor alpha-blocking agents in two patients with SAPHO syndrome. Arthritis Rheum 2002:46:1965-8.

36 Huber AM, Lam PY, Duffy CM, Yeung RS, Ditchfield M, Laxer D, et al. Chronic recurrent multifocal osteomyelitis: clinical outcomes after more than five years of follow-up. J Pediatr 2002;141:198-203.

37 Girschick HJ, Krauspe R, Tschammler A, Huppertz HI. Chronic recurrent osteomyelitis with clavicular involvement in children: diagnostic value of different imaging techniques and therapy with non-steroidal anti-inflammatory drugs. Eur J Pediatr 1998;157:28-33.

38 Krauspe R, Girschick H, Huppertz HI. Lymphoplasmacellular osteomyelitis. Orthopade 1997:26:894-901.

39 Lane D. 16S/23S rRNA sequencing. In: E Stackebrandt MG, eds. Nucleic acid techniques in bacterial systematics. Chichester, UK: Wiley, 1991:115-75.

40 Goldenberger D, Kunzli A, Vogt P, Zbinden R, Altwegg M. Molecular diagnosis of bacterial endocarditis by broad-range PCR amplification and direct sequencing. J Clin Microbiol 1997;35:2733-9.

41 Petty RE, Southwood TR, Baum J, Bhettay E, Glass DN, Manners P, et al. Revision of the proposed classification criteria for juvenile idiopathic arthritis: Durban, 1997. J Rheumatol 1998;25:1991-4.

42 Amor B, Dougados M, Listrat V, Menkes CJ, Dubost JJ, Roux H, et al. Evaluation of the Amor criteria for spondylarthropathies and European Spondylarthropathy Study Group (ESSG). A cross-sectional analysis of 2,228 patients. Ann Med Interne (Paris) 1991;142:85-9.

43 Dougados M, van der Linden S, Juhlin R, Huitfeldt B, Amor B, Calin A, et al. The European Spondylarthropathy Study Group preliminary criteria for the classification of spondylarthropathy. Arthritis Rheum 1991;34:1218-27.

44 Helkimo M. Studies on function and dysfunction of the masticatory system. II. Index for anamnestic and clinical dysfunction and occlusal state. Sven Tandlak Tidskr 1974;67:101-21.

45 Giedion A, Holthusen W, Masel LF, Vischer D. Subacute and chronic "symmetrical" osteomyelitis. Ann Radiol (Paris) 1972;15:329-42.

46 Lissens M, Bruyninckx F, Rosselle N. Condensing osteitis of the clavicle. Report of two cases and review of the literature. Acta Belg Med Phys 1990;13:235-40.

47 Appell RG, Oppermann HC, Becker W, Kratzat R, Brandeis WE, Willich E. Condensing osteitis of the clavicle in childhood: a rare sclerotic bone lesion. Review of literature and report of seven patients. Pediatr Radiol 1983;13:301-6.

48 Jani L, Remagen W. Primary chronic osteomyelitis. Int Orthop 1983;7:79-83.

49 Huaux JP, Esselinckx W, Meunier H, Malghem J, Maldague B, Nagant de Deuxchaisnes C. Pustulotic arthro-osteitis in children and adults. A report of 13 cases. Clin Exp Rheumatol 1987;5:143-6.

50 Huaux JP, Esselinckx W, Rombouts JJ, Maldague B, Malghem J, Devogelaer JP, et al. Pustulotic arthroosteitis and chronic recurrent multifocal osteomyelitis in children. Report of three cases. J Rheumatol 1988; 15:95-100.

51 Trobs R, Moritz R, Buhligen U, Bennek J, Handrick W, Hormann D, et al. Changing pattern of osteomyelitis in infants and children. Pediatr Surg Int 1999; 15:363-72.

52 Leirisalo-Repo M. Enteropathic arthritis, Whipple's disease, juvenile spondyloarthropathy, uveitis, and SAPHO syndrome. Curr Opin Rheumatol 1995: 7:284-9.

53 Bjorksten B, Gustavson KH, Eriksson B, Lindholm A, Nordstrom S. Chronic recurrent multifocal osteomyelitis and pustulosis palmoplantaris. J Pediatr 1978;93:227-31

54 Cole WG. The management of chronic osteomyelitis. Clin Orthop 1991:84-9.

55 Hayem G, Bouchaud-Chabot A, Benali K, Roux S, Palazzo E, SilbermannHoffman O, et al. SAPHO syndrome: a long-term follow-up study of 120 cases. Semin Arthritis Rheum 1999;29:159-71. 